\title{
In search of the élite
}

\section{A huge number of people have contributed to the success of San Diego. Virginia Gewin catches up with a selection of the region's prime movers.}

$\mathbf{T}$

he rise of San Diego has been remarkable. In just 30 years, it has secured itself a prime position in the world of biotech and high-tech innovation. But who helped to shape this vision? Who ensured that the region did not buckle under the pressures of recession?

There are many names on this roll of honour - those who facilitated San Diego's rejuvenation, those whose entrepreneurial vision has laid the foundations for the region's meteoric rise, and those upon whom the area's future prosperity will depend. Nature canvassed dozens of San Diego insiders to find out who they believed to be the élite. Among the 270 responses, several names cropped up again and again. Although by no means an exhaustive list, here, in no order of merit, are those who were mentioned most often.

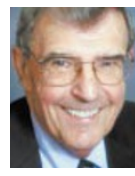

\section{Bob Beyster}

Chief executive of Science Applications International Corporation (SAIC). GREATEST ACHIEVEMENT Founding SAIC in 1969; and 34 years of increased revenues and consistent growth for our employee owners - the company has never had a downturn year. мотто Those who contribute to the company should own it. TODAY'S TELECOM INDUSTRY It has been experiencing a downturn for the past couple years. We are optimistic that there will be a turnaround soon. SURPRISING FACT When I started SAIC in 1969, I was never very much concerned about the money aspect of the job. I wanted to create an environment where we would not be bothered by bureaucracy and other considerations that made it hard to do research. BIGGEST ANNOYANCE Losing business to a competitor. BEST PART OF JOB Solving extremely complex problems that ultimately benefit the country.

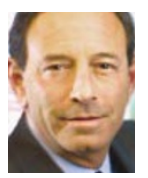

\section{Howard} Birndorf Chief executive of Nanogen, founding partner of Hybritech and IDEC Pharmaceuticals. SAN DIEGO AND HYBRITECH I have to believe that in time there would have been another biotech happening here because there were so many talented individuals. But it was a magical place — everybody was committed and worked hard with a sense of excellence and urgency to get the job done. GREATEST ACCOMPLISHMENT With Hybritech it was the prostate cancer test, which has saved countless lives. I think the other great success was Rituxan, an antibody treatment that attacks cancer cells, from IDEC. ENTREPRENEURSHIP IN SAN DIEGO It needs to be a good idea and have commercial merit, but you can get it done here easier than anywhere else in the world. PIVOTAL MOMENT IN YOUR CAREER Meeting venture capitalist Brook Byers and working with him for 25 years. He's an amazing businessman and incredible mentor - one of the brightest people I know. IMPACT OF NANOTECH ON BIOTECH Miniaturization is king; it will open entirely new markets.

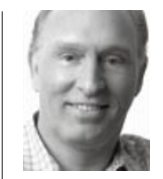

Bob Conn

Partner at the venturecapital firm Enterprise Partners, former dean of the Jacobs School of Engineering at the University of California, San Diego.

мотто You shouldn't do anything for more than a decade.

HOBBIES Contemporary art is a passionate interest. It goes back to my early days when friends were artists and I was a nerd.

PIVOTAL MOMENT OF CAREER The moments of change. I made some major changes in my career: I left the University of Wisconsin to go to the University of California, Los Angeles, then on to its San Diego campus. Finally I joined Enterprise Partners. RECENT TRENDS As I get older I take more risks.

STATE OF HIGH-TECH IN SAN DIEGO We're without peer in the wireless area. It is the Silicon Valley of wireless. I don't want to sound like a city booster, but I suppose I am. I think that the foundation that has been laid for San Diego's economy in the past two decades has put the city in an extraordinary position for the next ten years.

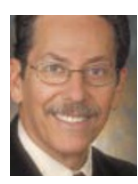

\section{Ron Evans}

Professor of molecular biology at the Salk Institute and a Howard Hughes investigator. Founder of several companies including Ligand Pharmaceuticals, Xceptor Therapeutics and

Xenopharm.

GREATEST ACHIEVEMENT The discovery of a large family of hormone receptors that are potential targets for cancer therapy, and the characterization of a mechanism of action that revealed how hormones and drugs control wide aspects of body physiology and disease. BIGGEST CHALLENGE TO FORMING LIGAND Raising money. Big pharmaceutical companies weren't interested in new technology primarily because they didn't understand how it could be used. DRIVING FORCE Helping to cure disease. Taking a discovery from the lab bench, through a company and into the clinic is amazing. NEXT BIG THING IN BIOTECH

The next era will be the commercialization of the human genome, the integration of new concepts that will explore large numbers of proteins as potential therapeutic targets.

HOPE FOR CHANGE Some understanding by the Food and Drug Administration that every single drug should not cost $\$ 900$ million to create and test. Such a burden means that only big companies can afford to bring drugs to the market-place. SURPRISING FACT I like fast cars. BEST PART OF JOB Blue sky-ing with colleagues about big questions in biology.

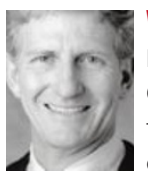

Wain Fishburn

Partner with law firm Cooley Godward, founding member of BIOCOM and UCSD CONNECT. GREATEST ACHIEVEMENT Realizing in the late 1980s that the lifescience and technology industries were likely to be the key factors for San Diego's future - even though at the time every one else thought I was crazy. 
PIVOTAL CAREER MOMENT When San Diego matured as a lifescience and technology venture community and the major law firms saw fit to open offices here. As a lawyer, I had always had to fight to demonstrate that what was happening in San Diego was important.

BEST THING ABOUT SAN DIEGO It has outgrown its caricature as a place with great sun and airheaded surfers. Over the past 20 years we have become a Mecca for the best and brightest in myriad tech fields. SURPRISING FACT I dance when no one is looking.

TEN-YEAR FORECAST I'm curious as to whether we end up with a meaningful number of standalone companies or go in our present direction of supplying major corporations with promising companies.

FAVOURITE PLACE IN SAN DIEGO I love meeting entrepreneurs in the evening for a glass of wine on the balcony of La Valencia hotel.

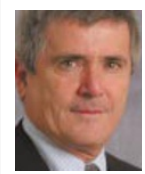

Itzhak Gurantz

Chief executive of Entropic

Communications, and instrumental in the

development of Direct TV.

MENTOR Andy Viterbi, co-founder of Qualcomm.

\section{GREATEST ACHIEVEMENT}

Developing the transmission standard and technology for Direct TV, or satellite broadcast television, especially considering its impact — and the number of doubters who questioned whether it would be valuable.

BEST PART OF JOB Working with young engineers - working and mentoring is what I enjoy.

\section{WORST THING ABOUT SAN DIEGO}

Trying to recruit key executives. I wanted to hire a chief executive for a company, and a lot of those whom I considered to be qualified candidates indicated that the Bay Area was a much more favourable place for them to work.

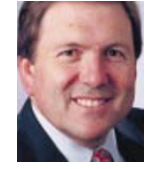

David Hale

Chief executive of CancerVax and a founding member of Hybritech, BIOCOM and UCSD CONNECT. HOW SAN DIEGO HAS CHANGED When I first came here, most people had no idea what biotechnology was, what its capabilities might be or knew anything about science or industry. I remember organizing a day with the city council where a number of us presented what we thought the potential was for the industry and they were flabbergasted. Additionally, we used to have to hire every employee from somewhere else. There wasn't anybody here that knew anything. PERSONAL FAILURE My greatest personal disappointment was to have Protera - a product to reduce deaths and stroke during coronary bypass surgery - fail in the final stage of clinical trials at Gensia.

BIOTECH INDUSTRY FAILURE The industry as a whole has failed to grow independent biotech companies in San Diego. FUTURE OF BIOTECH I think over the next several years, we'll have companies that can sustain growth and development in San Diego. Companies are structuring agreements so that it will make it more difficult for other companies to come and buy them.

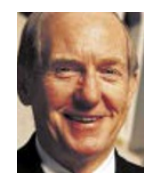

\section{Ed Holmes}

Health sciences vicechancellor and dean of the medical school at the University of

California, San Diego.

EXCITING PROJECT PharmaSTART is the partnership between the University of California's San Diego and Los Angeles campuses, Stanford University and SRI International to move ideas or concepts out of labs and into new drugs to improve health.

ROUTE TO SUCCESS PharmaSTART goes to the private sector with ideas to bridge the gap between discovery and the private sector. The roadblock in the 'translational highway' of moving ideas to the market-place is when an idea gets stuck at the point when its funding from the National Institutes of Health has ended, but it has yet to secure pre-seed money for a start-up. A lot of really good ideas are too early for venture capitalists to pick up and need to be matured. We want to bring an idea closer to the clinic so that the private sector might be more motivated to pick it up. GREATEST ACHIEVEMENT Working with faculty members and leadership to develop a vision for institutions that capitalizes on their strengths and matches where the forefront of science is heading. BEST PART OF SAN DIEGO What is unique about San Diego's academic excellence is a constellation of things - a group of institutions such as Salk, Burnham, Scripps layered on top of a robust biotech industry. BEST PART OF JOB Bringing creativity and so making it easier for faculty members to do their research.

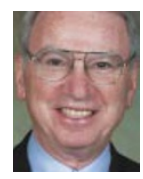

\section{Irwin Jacobs} Chief executive of Qualcomm. Founded both Qualcomm and Linkabit, the company that sparked the rise of San Diego's telecom industry and led to dozens of companies.

GREATEST ACHIEVEMENT I feel it is the development and worldwide acceptance of code division multiple access (CDMA) digital wireless technology that creates a unique code for each call and so allows greater sharing of the airwaves.

MENTOR Claude Shannon, the father of information theory and a fellow faculty member at the Massachusetts Institute of Technology.
GREATEST BUSINESS FAILURE OUI delay in entering key markets in Asia and Europe.

CURRENT STATE OF THE TELECOM INDUSTRY I think that it is slowly recovering, led by strong growth in CDMA communications, powerful and attractive devices, and a rapidly expanding range of applications.

BEST AND WORST OF SAN DIEGO

There are continuing

improvements in the cultural and intellectual climate to match our physical climate - although these are offset by the need for improvements in housing, transportation and public education.

SURPRISING FACT I had difficulty at college with public speaking (I almost flunked) and cooking (while in the Cornell hotel school).

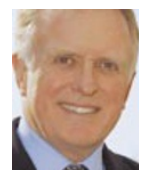

\section{Robert Kibble} Managing partner at Mission Ventures and early-stage investor in over 30 high-tech

companies in California.

GREATEST BUSINESS FAILURE It's difficult to choose between them. The most recent one was the Internet company Ihome which went bust just after the bubble burst in 2001. We just couldn't support it with additional capital.

NEXT BIG THING It's occurring right in front of our eyes - access to information from any device anywhere, complete mobility. SAN DIEGO LACKS It would be nice to have a few more Qualcomms. And, we don't have a world-class business school. As a businessman, I see that as a negative.

HOW VENTURE CAPITAL HAS CHANGED In general, the past ten years have seen more firms and money - and it's become more institutionalized in the way it operates. HOBBIES Until recently, horse rider and fox hunter. 


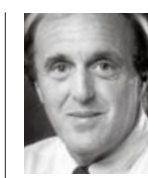
Richard Lerner

President of the Scripps Research Institute. GREATEST ACHIEVEMENT Building Scripps into what it is today. CHALLENGE OF RUNNING SCRIPPS Finding the resources necessary to continue to fuel the science engine that we are today.

PIVOTAL MOMENT IN CAREER Discovering the first catalytic antibodies in 1986.

FUTURE OF BIOTECH No matter what happens to the economy, people will always need new medicines.

\section{NEXT BIG THING IN BIOTECH}

Scripps researcher Pete Schultz's unnatural amino acids.

SURPRISING FACT I'm an excellent golfer.

NEXT FOR SCRIPPS We've just signed a deal in which we've got more than $\$ 500$ million to establish a new centre in Florida that will focus on drug discovery. PREDICTION FOR SAN DIEGO There's not a lot of space left, so I think the way it will evolve is that some younger companies will mature, while the research will continue to be great.

BEST PART OF YOUR JOB Getting to do my own science and interacting with the great scientists at Scripps.

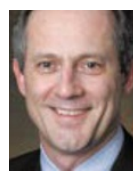

\section{Fred Muto}

Partner at the law firm Cooley Godward, has worked with, or represented, over 500 technology companies in California CHARACTERIZE SAN DIEGO I used to live in the Bay Area and San Diego is a much more tightly knit, supportive community. The Bay Area is a federation of communities loosely held together. CURRENT WORKLOAD I'm working with 60 tech companies right now — biotech, wireless and telecom. CURRENT STATE OF BIOTECH The mood is very positive right now.
A lot of guarded optimism about companies and products. FUTURE OF BIOTECH I see the future of the pharmaceutical industry as the future of the biotech industry. CURRENT STATE OF TELECOM

Telecom remains extremely challenging. It's a huge market with a great future, but it is still a market that is continuing to contract. BEST PART OF JOB Helping companies that make profound differences and feeling like you did a little more than practise law.

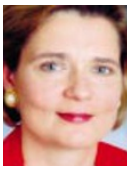
Gail Naughton Dean of the San Diego State University Business School, founder of Advanced

Tissue Sciences. GREATEST ACCOMPLISHMENT I invented a method for growing tissue in three-dimensional scaffolding placed in a bioreactor to simulate conditions found inside the human body. This led to the formation of Advanced Tissue Sciences and to its five products for treating severe burns, diabetic wounds, genetic skin disorders and cosmetic repair. MOST EXCITING DAY When I was the first individual woman to receiver the Intellectual Property Owners Association Inventor of the Year award in 2000

GREATEST FAILURE Not being able to keep Advanced Tissue Sciences from filing for bankruptcy in October last year. Although at the time, we had two strong marketing partnerships, three products on the market, and a fourth about to be approved, the revenues were disappointing for us and our two competitors. Within two weeks all three tissueengineering companies with products on the market failed. PIVOTAL MOMENT IN CAREER Deciding to form a company based on the tissue-engineering discovery even though my institution believed that the technology could not be patented. I was told: 'If it was a good idea someone would have thought of it already' and given back rights to the technology.

SURPRISING FACT When I was a new graduate student there were two things that I knew as fact I was never going to work in a company (never mind start one) and I was never going to have children (I now have three). I certainly learned never to say never.

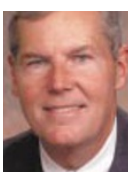

Hank Nordhoff

Chief executive of Gen-Probe, board member of the cancer centre at the University of California, San Diego, and vicechair of the Economic Regional

Development Corporation. FASTEST GROWING SECTOR FOR GEN-PROBE Blood screening. We've developed tools to check donated blood for certain viruses including hepatitis $\mathrm{C}$, and we're working on equipment to test for hepatitis B and West Nile virus. MOST RECENT ACCOMPLISHMENT The National Institutes of Health called us last year concerned about West Nile virus and asked for a product to screen blood in time for the peak mosquito season in July 2003. We were able to turn one around and managed to intercept 400 units of blood that contained the virus. BIGGEST FAULT I'm too slow to make personal changes.

PET ANNOYANCE People who don't use what they have as well as they could.

SURPRISING FACT I used to teach Sunday School, I've climbed Kilimanjaro and I was squash champion of Wilton, Connecticut, one year.

\section{NEXT BIG THING IN BIOTECH}

Customized medicine and pharmacogenomics - being able to predict the probability of someone coming down with a disease and taking preventative measures.

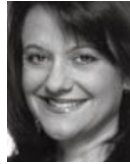

Tina Nova

Chief executive and founder of GenOptix, former president and former board member

of Nanogen. GREATEST ACHIEVEMENT Being part of teams that have successfully put products on the market that have made an impact in medical sciences. Nothing that you do can feel better than that. PIVOTAL MOMENT OF CAREER Deciding to go from academia to commercial industry.

HOBBIES Politics. I advise some of the political leaders on scientific matters, and I host fundraisers. I'm the California chair of the Democratic Leadership Council. BEST ADVICE Don't let anything get in the way of what you want to accomplish.

MENTOR Somebody called me one day and said: 'I hear you are in charge of Democrats in Biotech.' I called UCSD CONNECT founder Bill Otterson and told him how strange that was, and he said: 'Oh, I made that up. We need that and I put you in charge of it.' SURPRISING FACT I enjoy playing $Y u$-gi-oh cards with my eight-yearold son. They're like Pokemon cards.

PET ANNOYANCE I prefer not to be around people who aren't passionate about something. SAN DIEGo I wouldn't leave here for anything. You could double or triple my salary to move and I wouldn't do it.

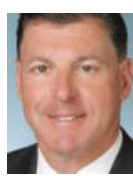

\section{Joe Panetta}

First and current chief executive of BIOCOM. BEST THING ABOUT SAN DIEGO When you get out of work in the afternoon the sun's out and you can go to the beach or surf any day of the year. On the business side, I like the simple fact that people here are not only friendly but interested in your success. 
WORST THING ABOUT SAN DIEGO

Although I wouldn't call it a

'worst', one of the most

challenging things is the very

strict environmental regulation

and duplication of federal

regulation in California.

BEST PART OF JOB I have the

opportunity to be involved in a

little bit of what's happening in

400 biotech companies at once. I

spend two or three lunch hours a

week visiting chief executives and

touring companies - learning

from them how to address their

challenges. It is the greatest job in

biotech in San Diego.

STATE OF THE BIOTECH INDUSTRY I

really can't begin to express my

enthusiasm for what

biotechnology will offer in the

future. Not only in terms of health,

but also in food production,

efficient manufacturing processes

- the potential benefits are

almost endless.

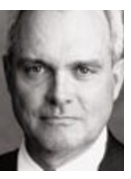

\section{Bill Rastetter}

Chief executive of IDEC Pharmaceuticals, who sealed the merger between Biogen and IDEC - creating the third largest biotech company in the world.

MENTOR Brook Byers of Kleiner

Perkins Caufield \& Byers venturecapital firm.

\section{STATE OF BIOTECH IN SAN DIEGO}

Successful companies are getting bigger, and smaller companies are getting creative. The drug industry is realizing that it has to add biotech tools into its discovery or product development mix. It's a sector that has come into its own. The sector is still not profitable, but a good number of large biotech companies are and are growing rapidly.

\section{BEST THING ABOUT SAN DIEGO}

Going to work and not putting

on snow tyres.

SURPRISING FACT I was born in

Panama.

новBIES Photography, swimming and golf.
GREATEST BUSINESS FAILURE The start-up technology that IDEC created did not succeed. We had to restart the company in 1993, in our seventh year, but we turned

failure into success.

NEXT BIG THING IN BIOTECH

Closing of the deal between Biogen and IDEC.

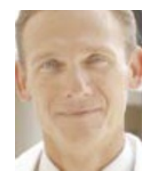

\section{John Reed}

President and chief executive of the

Burnham Institute, and co-founder of

\section{Idun Pharmaceuticals.}

\section{NEXT FOR BURNHAM We have a}

couple of initiatives under way including an effort that has more than 100 people working on stemcell biology. The other, the cancer drug-discovery initiative, will establish the facilities for structure-based drug discovery. BEST THING ABOUT SAN DIEGO The track record for public-private partnerships and entrepreneurial spirit.

PIVOTAL CAREER MOMENT While working on my MD/PhD, I went to Cold Spring Harbor Laboratory in New York for a three-week advanced cloning course and there was no more ambiguity - I wanted to do research.

MOST RECENT ACCOMPLISHMENT I just did the Lance Armstrong Tour of Hope bike ride. Also, while finishing my $\mathrm{PhD} / \mathrm{MD}$ at the University of Pennsylvania, I discovered a drug that targets a key gene known to make cancer cells immortal. The drug restores normal cell-death processes to the cancer cell and has just successfully finished the final stage of clinical trials. As a result, it seems to stand a good chance of becoming a new drug for treating cancer.

RISKY VENTURE I started Idun Pharmaceuticals based on a combination of technology from my laboratory and similar work by leaders in the field of apoptosis, or cell death. We merged the technologies under one umbrella organization in order to get venture-capital funding. We talked to big pharmaceutical companies, but they said that it was too early to use this research for cancer treatment as it was still unproven. The only way to get ball rolling was to start a company ourselves.

SURPRISING FACT I get up at 3:00 am every morning.

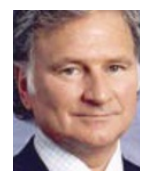

\section{Duane Roth}

Chairman and chief executive of Alliance Pharmaceuticals, executive committee member for UCSD CONNECT. CURRENT STATE OF BIOTECH IN SAN DIEGO If you look from the skies way above and identify the hot spots of biotechnology development on the planet, San Diego is a big, bright, red light. This is the result of two factors. First, is the University of California's campus - a 40-yearold university that went from an idea to phenomenal success. We recruited the most talented people and gave them academic freedom, which spilled over as the biotech industry started to emerge. Second, people in this area take risks — both scientific and financial.

BEST THING ABOUT SAN DIEGO We understand creative economies here. Biotech firms can have years of losses, and not make a profit until much later.

\section{WORST THING ABOUT SAN DIEGO}

The tough part for me is airplanes — it is a long way to go anywhere. I'd like to see more financial markets move into San Diego, more capital formation here. PIVOTAL MOMENT OF CAREER The adversity I faced on 8 January 2001, when I was told we had a potential problem that would cause us to stop working on a promising product. In the pharmaceutical industry, we live, breathe and die by our products.

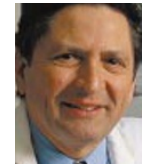
Ivor Royston Co-founder of Forward Ventures and of Hybritech. PIVOTAL CAREER MOMENT I was reading about monoclonal antibodies in Nature in 1975, and I thought: 'That's it, I'm going to use this new technology to develop new treatments for cancer'. Within six months of being at the University of California, San Diego I had made antibodies - I was the first in the area to make monoclonal antibodies.

BEST PART OF WORKING IN SAN DIEGO There is no better place that runs the spectrum of biology. La Jolla is like one big National Institutes of Health campus. It is equal or better than the Bay, Boston or Cambridge.

GREATEST BUSINESS FAILURE I feel badly about it because friends coinvested with me. It was a company to breed severe combined immunodeficiency disease (SCID) mice. It was a disaster because of intellectualproperty issues. HISTORY I've been intimately involved with forming 15 companies. But in the early years, I was pariah in science because it was not accepted to be involved in business. Now, it is very well accepted.

UNUSUAL FACT I had a production company, Pacific West

Entertainment, in Hollywood. We made some B movies, such as SoulTaker. It is proof that not everything I do turns to gold.

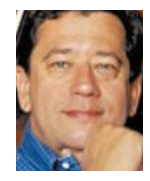
Drew Senyei Partner in venturecapital firm Enterprise Partners. MISCONCEPTION ABOUT VENTURE CAPITALISM HOW hard it is to move technology out of the lab and into commerce. For every dollar needed for invention, you need ten for commercialization. 
ORIGINAL PROFESSION I left the practice of medicine in 1987 , but I've always been an entrepreneur. I started a biotech company as a third-year medical student. It was called Molecular Biosystems and was basically my 'street MBA'. BEST THING ABOUT SAN DIEGO We have the highest per capita of Nobel laureates, most prolific publishing scientists, and a real sense of community that develops around the biotech sector. GREATEST ACHIEVEMENT I've done 25 deals since 1987 when I joined the partnership.

\section{ALTERNATIVE PROFESSION If} wasn't doing venture capitalism, I would like to be a rock star. SURPRISING FACT I'm fluent in Hungarian and cook a mean chicken paprikash. Also, I'm a bit of an amateur inventor. I have 30 patents. One is the first and only test approved by the Food and Drug Administration to predict premature birth 2-3 weeks ahead of time.

PET ANNOYANCE The perception that San Francisco is the centre of the Universe.

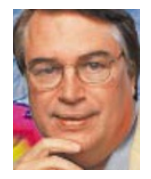

\section{Larry Smarr}

Director of the California Institute for Telecommunications and Information

Technology $\left(\mathrm{Cal}-(\mathrm{IT})^{2}\right)$.

GREATEST ACHIEVEMENT I think

that I have consistently been a

midwife for a whole series of what has become a part of the nation's information infrastructure. I argued strongly for the construction of the first national 'backbone', which connected the National Science Foundation's five supercomputer centres in 1986, and rapidly evolved, first into the NSFnet, and then into today's commercial Internet.

PRESENT AND FUTURE Technology change comes in these 10-20 year 'S' curves. I claim that what really created Silicon Valley was a co-evolution of the wired
Internet and the PC - sort of like in 1920s when it was the automobile and the road system. What is taking off now is wireless Internet and endpoints - mobile phones, sensor networks and personal digital assistants. FUTURE FOR YOUR CAL-(IT) ${ }^{2}$ We're entering a rapid deployment period for our living laboratories, which are based on campus and serve as models for society's future technology demands. We are building tools such as large-scale optical networks, wireless Internet and sensornet - real-time sensors for monitoring factors such as environmental conditions. It's unusual work for universities to undertake, and is only possible because of our close partnerships with industry.

NEXT BIG THING The partnership between industry and four California institutes - Cal-(IT) ${ }^{2}$, California NanoSystems Institute, the Center for Information Technology Research in the Interest of Society, and the Institute for Bioengineering, Biotechnology and Quantitative Biomedical Research — to put in place a persistent collaborative framework across departments, campuses and between

universities and industry. If this works, it will be like moving to a higher metabolic level in the evolution of life.

\section{SURPRISING FACT I have about}

15 different species of orchids in full bloom in my house at any one time, and 120 more that are resting at the orchid babysitter in town.

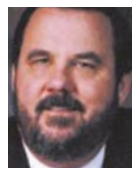

\section{Bill Stensrud}

Partner in venture-

capital firm Enterprise Partners.

FAVOURITE PLACE IN

SAN DIEGO The Torrey Pines South golf course. It is simultaneously a spectacular and profoundly humbling experience to play there. BEST THING ABOUT SAN DIEGO A great community of innovative and very smart engineers. WORST THING ABOUT SAN DIEGO

The cost of living and the airport. CURRENT STATE OF TELECOM The industry has been experiencing complete devastation for the past three years. San Diego has been somewhat protected because of its focus on wireless technologies.

The future of wireless is very bright and San Diego should emerge stronger in telecoms than it was before the crash.

\section{GREATEST BUSINESS FAILURE}

I have had so many it is hard to identify a greatest. On a grand scale, I completely failed to detect — early enough — the technology bust of the past three years. HOBBIES Music. I am past president and on the board of the San Diego Opera, and I play classical guitar very badly, but I enjoy it.

SURPRISING FACT I was a member of a world champion tiddlywinks team.

\section{GREATEST ACHIEVEMENT Being}

part of the founding management team of telecoms firm StrataCom. It was a terrific experience with a spectacular group of people. We invented the \$15-billion frame-relay industry, created tremendous shareholder value and had a lot of fun.

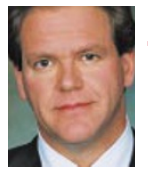

Marco Thompson Chairman of the San Diego Telecom Council and chief technology

officer of Wind River Systems. GREATEST ACHIEVEMENT: Retiring from entrepreneurship in my thirties to spend time with my family. I won't start my next company until summer 2008 when my son graduates from high school.

MENTOR The late Bill Otterson, founder of UCSD CONNECT. Bill was more responsible for the economic miracle of San Diego than any other person.

CURRENT STATE OF TELECOM I call the bottom 15 May this year. By then people were beginning to talk up revenues, to stop laying people off and some were hiring again. It has been nothing but up ever since. новвіЕS Hockey and heleskiing — every year I take about 20 of San Diego's high-tech chief executives heleskiing in Canada. PET ANNOYANCE We get annoyed if people do business with other companies when it could have been done locally. There are lots of services to connect people to San Diego first.

KEY TO SUCCESS It's a combination of who you know and knowing enough about people not to waste anyone's time.

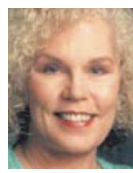
Julie Meier Wright Chief executive of the San Diego Economic Development Research Council. GREATEST ACHIEVEMENT California was viewed as a business-unfriendly state in the early 1990s. Under then Governor Pete Wilson's leadership we enacted wide-ranging businessclimate reforms and worked diligently to help companies grow or solve problems here. The result was a stunning turnaround in California's economy.

CURRENT BUSINESS ATMOSPHERE It's a new day in California with a new governor.

ADVICE TO THE NEW GOVERNOR

Address the budget problems responsibly so that the financial community has renewed confidence in California. MENTOR I have been blessed with many mentors. One of the best was Pete Wilson.

\section{WORST THING ABOUT SAN DIEGO}

The most challenging thing is what exists in the biotech industry almost everywhere - inadequate capital to fund number of ideas, some of which will turn into amazing products. SURPRISING FACT I rollerblade. Virginia Gewin is a freelance writer based in Corvallis, Oregon. 